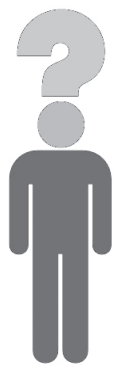

Społeczeństwo odpowiedzialne? O aspektach odpowiedzialności

w życiu społecznym jednostek, red. K. Cikała, W. B. Zieliński, Kraków 2015, s. 51-64

DOI: http://dx.doi.org/10.15633/9788374384254.06

Mateusz Trawiński

\title{
KAPITALIZM NIEODPOWIEDZIALNY
}

\section{JAK KRÓTKOWZROCZNE DZIAŁANIA REGULATORÓW, BANKÓW I KLIENTÓW PRZYCZYNItY SIĘ DO WYSTĄPIENIA KRYZYSU FINANSOWEGO}

Kryzys finansowy, który rozpoczął się 15 września 2008 roku - w tym dniu bank inwestycyjny Lehman Brothers ogłosił upadłość - zachwiał stabilnością finansową prawie całego współczesnego świata. Niemal od razu pojawiły się pytania o to, kto jest odpowiedzialny za jego wystąpienie. Pojawiło się wiele hipotez - wskazywano m.in. na kult ryzyka, którym charakteryzuje się współczesny świat finansów, przymykanie oka na nieprawidłowości przez instytucje regulujące rynek lub złożoność systemu finansowego.

Z perspektywy niniejszego wywodu warto podkreślić, że odpowiedzialność może mieć dwojaki charakter. Pierwszy rodzaj odpowiedzialności określany jest w języku angielskim jako responsibility. W tej perspektywie szukamy przyczyny danych wydarzeń, osoby, osób lub instytucji, których działania bądź zaniechanie działań dały początek zaistnieniu danego zdarzenia. Drugi rodzaj odpowiedzialności to accountability. W tym przypadku chodzi o kwestię odpowiedzialności, najczęściej prawnej, za rezultaty będące konsekwencją działania/zaniechania. W niniejszym tekście analizujemy pierwszy z wyszczególnionych wymiarów. Wywód ten pokaże też jednak, jak złożonym problemem jest accountability. Każdy z opisanych poniżej aktorów działa bowiem w przestrzeni interesów, wpływów i instytucji, które nakłaniają go do podjęcia określonych działań, w krótkiej perspektywie bardzo racjonalnych. Niestety skala nieodpowiedzialnych zachowań i rozprzestrzenienie tego zjawiska może doprowadzić do tragicznych skutków, których w przypadku kryzysu finansowego 2008 doświadczamy do dziś.

W chwilach kryzysu, w tym finansowego, pojawia się również problem tego, na jakich zasadach można poprawić istniejący, a nieefektywny system gospo- 
darczy, techniczny lub społeczny. Z perspektywy niniejszego wywodu warto wskazać cztery podstawowe elementy, którymi musiałby się charakteryzować odpowiedzialny kapitalizm. System taki:

- umożliwia realizację strategii długoterminowych w przeciwieństwie do krótkoterminowych;

- umożliwia zrównoważony rozwój przedsiębiorstw i społeczeństwa;

- chroni przed uzyskaniem pozycji hegemonicznej przez wybraną gałąź gospodarki;

- chroni konsumentów w sektorach, w których zasady rynkowe są ograniczone.

Wcielenie w życie tych czterech zasad uniemożliwiłoby wykorzystywanie przewagi, która we współczesnym kapitalizmie została przypisana sektorowi finansowemu. Zaprezentowane $\mathrm{w}$ niniejszym tekście studium przypadku jest egzemplifikacją tego zjawiska. O odpowiedzialnym kapitalizmie nie można by jednak mówić w kontekście kryzysu finansowego bez poruszenia problemu bezpieczeństwa ekonomicznego.

\section{Bezpieczeństwo ekonomiczne}

W niniejszym artykule bezpieczeństwo ekonomiczne definiować będziemy za Lanem Kenworthym jako „posiadanie wystarczających i racjonalnie stabilnych dochodów, aktywów i wydatków"1. W takiej artykulacji bezpieczeństwo ekonomiczne można do pewnego stopnia utożsamiać z koncepcją zrównoważonego rozwoju. Ideą bezpieczeństwa ekonomicznego jest zwrócenie uwagi na konieczność projektowania systemów efektywnych w długim okresie, w przeciwieństwie do strategii krótkowzrocznych, niezdolnych do zapewnienia stabilnego dobrobytu.

Bezpieczeństwo ekonomiczne - a w przypadku niniejszego tekstu jego fundamentalny element - bezpieczeństwo sektora finansowego - jest tu pojęciem kluczowym również z uwagi jego podstawowe znaczenia we współczesnym świecie. Jak pokazał kryzys finansowy 2008 roku, wiele gałęzi gospodarki oraz

1 L. Kenworthy, Economic security. Course at sociology and political science, http://www.u.arizona.edu/ /kenwor/indv102economicsecurity.pdf (14.05.2014). 
ład polityczny i społeczny mogą zostać naruszone w przypadku pojawienia się strukturalnych problemów w sferze finansowej. Sheila Ronis zwraca uwagę, że

Bezpieczeństwo ekonomiczne jest głównym elementem bezpieczeństwa narodowego [...]. Bez względu na to, jak patrzymy na bezpieczeństwo narodowe, nie ma wątpliwości, że trzeba w nie włączyć potencjał ekonomiczny. Bez kapitału nie ma biznesu, bez biznesu nie ma zysków, bez zysków nie ma miejsc pracy. A bez miejsc pracy nie ma podatków, a więc możliwości obrony militarnej państwa².

\section{Relacja agencji}

Teoria agencji, znana również pod nazwą teorii pryncypała-agenta, jest rozwijana głównie w ramach ekonomii ${ }^{3}$. Opisuje jednak podstawową relację społeczną istniejącą nie tylko w sferze ekonomicznej, ale przede wszystkim w każdym obszarze społeczeństwa opartego na podziale pracy społecznej ${ }^{4}$. Opisanie relacji agencji jest więc elementem budowania ogólnej teorii społecznej.

Próbując określić zakres opisowy teorii agencji, możemy odwołać się do definicji sformułowanej przez Stephena Rossa, który pisał, że

relacja agencji powstaje między dwiema (lub więcej) stronami, gdzie jedna określana jako agent działa dla, w imieniu lub jako reprezentant drugiej określanej jako pryncypał. Przykłady agencji są uniwersalne. Zasadniczo wszystkie porozumienia mające postać kontraktów, jak między pracodawcą i pracownikiem lub państwem i rządzonymi, zawierają istotne elementy agencji ${ }^{5}$.

Teoria agencji ma na celu opisanie sytuacji związanych z delegowaniem zadań i odpowiedzialności, czyli podstawami działania zbiorowego. Podstawowe założenia teorii agencji prezentuje w książce dotyczącej teorii organizacji Charles Perrow:

Trzy założenia są rdzeniem teorii agencji. Pierwsza [...]: jednostki maksymalizują własne korzyści. Druga jest bardziej specyficzna dla teorii agencji: życie społeczne jest

2 S. R. Ronis, Preface, [w:] Economic security. Neglected dimension of national security?, ed.

S. R. Ronis, Washington 2011, s. 8.

3 S. Shapiro, Agency theory, „Annual Review of Sociology” 31 (2005), s. 265.

4 É. Durkheim, O podziale pracy społecznej, Warszawa 2011.

5 S. Ross, The economic theory of agency: the principal's problem, "American Economic Review” 63 (1973), s. 134. 
serią kontraktów lub wymian rządzonych przez rywalizujące ze sobą interesy własne [jednostek]. Trzecia odnosi się do wewnętrznej analizy organizacji: monitorowanie kontraktów jest kosztowne i do pewnego stopnia nieefektywne, zwłaszcza w organizacjach, a to zachęca do zachowań egoistycznych, uchylania się od obowiązków, oportunizmu [...] lub po prostu oszukiwania. Kontrakty będą łamane ze względu na egoizm i mogą być łamane ze względu na koszty i nieefektywność nadzoru ${ }^{6}$.

Spektakularny rozwój cywilizacji zachodniej i sukces wolnego rynku pokazują, że system społeczny oparty na złożonym podziale pracy, czyli rozbudowanych relacjach agencji, jest bardzo efektywny. Teoria agencji zwraca jednak uwagę na fakt, że każda tego typu relacja pociąga za sobą koszty. Są nimi problemy agencji. W literaturze przedmiotu można wyróżnić ich wiele - z perspektywy niniejszego tekstu będzie nas interesowało pięć z nich:

1. Negatywna selekcja - pryncypał niemal nigdy nie może sprawdzić rzeczywistych kompetencji agenta. Stąd selekcja agentów musi przebiegać za pomocą wskaźników. Wskaźniki jednak nigdy nie odzwierciedlają praktycznych kompetencji agentów, stąd proces selekcji przechodzą nie najbardziej kompetentni kandydaci, ale ci, którzy najlepiej poradzili sobie w procesie rekrutacyjnym?

2. Oportunizm agenta - żaden agent nie jest kontrolowany we wszystkich aspektach działań. W trakcie wykonywania swoich zadań agent może wykorzystać nadarzające się okazje umożliwiające odniesienie mu osobistej korzyści kosztem swojego pryncypała ${ }^{8}$. Problem okazuje się bardzo istotny ze względu na fakt, iż nie istnieją wystandaryzowane narzędzia rozpoznawania jednostek oportunistycznych w procesie rekrutacyjnym.

3. Asymetria informacji - agent, będąc oddelegowanym do wykonywania określonych zadań, jest zawsze lepiej poinformowany o rzeczywistej sytuacji w ramach powierzonych obowiązków. Przewaga informacyjna nad pryncypałem sprawia, że agent może wykorzystać swą wiedzę dla osiągnięcia celów sprzecznych z formalnie powierzoną mu rolą ${ }^{9}$. Asymetria infor-

6 C. Perrow, Complex organizations: a critical essay, New York 1986, s. 12.

7 K. M. Eisenhardt, Agency theory: an assessment and review, „Academy of Management Review" 14 (1989), s. 61.

8 E. Kiser, Comparing varieties of agency theory in economics, political science, and sociology: an illustration from state policy implementation, „Sociological Theory” 17 (1999), s. 163.

9 S. Shapiro, Agency theory, dz. cyt., s. 267. 
macji jest szczególnie ważna ze względu na fakt, iż jest systemowym czynnikiem umożliwiającym zachowania oportunistyczne.

4. Pokusa nadużycia - w przypadku relacji agencji część podejmowanych decyzji spoczywa na agencie. Może on ponosić, i najczęściej ponosi, ich konsekwencje. Jednak skutek działań agenta dotyczy nie tylko jego samego, ale również pryncypała. Pokusa nadużycia pojawia się w specyficznej sytuacji, gdy podmiot decyzyjny, który jest przynajmniej częściowo ubezpieczony (nie ponosi pełni konsekwencji swoich działań), zaczyna zachowywać się bardziej ryzykownie, niżby działał bez posiadania takiego ubezpieczenia ${ }^{10}$. Zjawisko pokusy wskazywane jest jako jedna z istotnych zmiennych, które miały wpływ na wystąpienie kryzysu finansowego ${ }^{11}$.

5. Konflikt interesów - cele pryncypała i agenta niemal nigdy nie są w pełni tożsame. Problem konfliktu interesów pojawia się, gdy sprzeczność między interesami pryncypała i agenta może wpływać na podejmowanie przez tego drugiego decyzji niezgodnych z jego formalnymi celami, którymi jest reprezentowanie interesów pryncypała ${ }^{12}$.

Jak widać z powyższych definicji, pięć podstawowych problemów agencji jest nie tylko ściśle związanych z istnieniem samej relacji pryncypała-agenta, ale również są to często problemy powiązane ze sobą, które trudno analizować w odosobnieniu. Fundamentalnym wyzwaniem, które staje zatem przed pryncypałem, jest konieczność monitorowania działań agenta. Jednak jak już wcześniej wskazano w cytacie Charlesa Perrowa - kontrola jest przyczyną dodatkowych kosztów, nie tylko ekonomicznych. Jednym z nich jest zwiększona złożoność całego systemu i dalsze rozbudowanie relacji agencji, gdyż kontrolerem najczęściej nie jest sam pryncypał, lecz kolejny agent. Generalnie stosuje się trzy podstawowe metody rozwiązywania problemów agencji:

1. Odpowiednia selekcja - system odpowiedniego doboru agentów jest kluczowy dla przełamania problemów agencji ${ }^{13}$. Niektórzy badacze zwracają uwagę na nieformalne czynniki wpływające na dobór agentów - czasami

10 C. Perrow, Complex organizations, dz. cyt., s. 20.

11 R. Masera, Taking the moral hazard out of banking: the next fundamental step in financial reform, „PSL Quarterly Review” vol. 64 (2011) no. 257, s. 105-142.

12 R. Waterman, K. Meier, Principal-agent models: an expansion?, „Journal of Public Administration Research and Theory" 8 (1998), s. 187.

13 T. M. Moe, The new economics of organization, „American Journal of Political Science" 28 (1984), s. 756. 
pryncypałowie starają się zatrudniać jednostki, które podzielają te same wartości i odznaczają się lojalnością ${ }^{14}$.

2. Mechanizmy kontroli - pryncypałowie tworzą określone narzędzia (np. audyt) umożliwiające sprawdzenie, czy agent działa zgodnie z ich interesem. Innym sposobem jest projektowanie bodźców i zachęt, mających przybliżyć cele agenta do celów pryncypała ${ }^{15}$.

3. Kontrakty - sama definicja relacji agencji podkreśla, że stosunek pryncypała i agenta ma formę kontraktu ${ }^{16}$. Podstawowym narzędziem kontroli agentów jest więc odpowiednie sformułowanie samego kontraktu. Mają one dwie zasadnicze postacie:

- Kontrakty zorientowane na zachowanie (ang. behavior-oriented contracts) - w przypadkach, gdy wynik wykonywanej pracy jest trudny do oszacowania lub wykonywane zadania są wysoce wystandaryzowane ${ }^{17}$, stosuje się kontrakty ustanawiające stałą stawkę godzinową lub miesięczną (np. wynagrodzenie urzędników). Pozytywną konsekwencją tego typu kontraktów jest unikanie pokusy nadużycia i zmniejszenie działań oportunistycznych przez agentów ${ }^{18}$. Podejmowanie nadmiernego ryzyka nie przyniesie bowiem dodatkowych korzyści materialnych. Z drugiej strony efektywność tego typu kontraktów powinna być nadzorowana przez zewnętrzne instytucje kontrolne, gdyż pryncypał nie może mieć pewności, że agent jest wystarczająco zmotywowany do rzetelnego wykonywania swoich zadań.

- Kontrakty zorientowane na wynik (ang. outcome-oriented contracts) - mają na celu zbliżenie interesów pryncypała i agenta. W ramach tego kontraktu agent jest w pełni lub w istnej mierze wynagradzany od wyników własnych działań ${ }^{19}$. Rozwiązanie to ma na celu stworzenie mechanizmu, w którym pryncypał mógłby polegać w dużej mierze na samoregulacji działań agentów bez potrzeby wprowadzania kosztownego

E. Kiser, Comparing varieties..., dz. cyt., s. 156.

15 B. M. Mitnick, Fiduciary rationality and public policy: the theory of agency and some consequences, paper presented at the 1973 Annual Meeting of the American Political Science Association, s. 14, http://ssrn.com/abstract=1020859 (14.05.2014).

16 S. Ross, The economic theory of agency..., dz. cyt., s. 134.

17 K. M. Eisenhardt, Agency theory, dz. cyt., s. 62.

18 A. Sharma, Professional as agent: knowledge asymmetry in agency exchange, "The Academy of Management Review" 22 (1997), s. 783.

19 K. M. Eisenhardt, Agency theory, dz. cyt., s. 59-60; T. M. Moe, The new economics of organization, dz. cyt., s. 763. 
monitoringu ich działań. W sektorze finansowym kluczowym elementem promowania wyników jest wypłacanie rocznych bonusów uzależnionych w większości wypadków od wyników finansowych firmy. Głównym problemem jest tu zwiększone zagrożenie pojawienia się pokusy nadużycia, która przejawia się m.in. w możliwości sztucznego zawyżania wyników firmy przez agentów, jak miało to miejsce w przypadku skandali Enronu i WorldComu ${ }^{20}$, aby otrzymać nienależne korzyści ${ }^{21}$.

Z perspektywy teorii agencji bezpieczeństwo ekonomiczne zależeć będzie w istotnym stopniu od uregulowania problemów agencji i praktycznej efektywności kontraktów zorientowanych na wynik. Zgodnie z dociekaniami teoretycznymi zastosowanie odpowiednich procedur regulacyjnych powinno $\mathrm{w}$ pełni zabezpieczyć interesy pryncypałów. Jednak liczne przypadki empiryczne pokazują, że we współczesnym kapitalizmie zastosowane rozwiązania instytucjonalne w niewystarczającym stopniu przyczyniają się do kontroli agentów. Systemowy charakter tego fenomenu może być jedną z istotnych przyczyn wystąpienia kryzysu finansowego w 2008 roku.

\section{Upadek banku Washington Mutual}

Washington Mutual Bank (WaMu) był szóstym największym bankiem w USA. Liczby prezentują się w tym przypadku, nawet biorąc pod uwagę wielkość tego sektora, imponująco - 300 miliardów dolarów w aktywach, 188 miliardów dolarów depozytów, ponad 40 tysięcy pracowników 22. Jednak nie był to bank „zbyt wielki, by upaść" - wniosek o bankructwo został złożony 25 września 2008 roku. Bezpośrednią przyczyną tego wydarzenia była utrata płynności spowodowana klasyczną paniką bankową - klienci zaczęli masowo wycofywać swoje depozyty. Jednak głębokie przyczyny tej upadłości są rozłożone w czasie, a część z nich leży w nieuregulowanych problemach agencji. Złożone relacje pryncypałów i agentów prezentuje poniższy schemat.

20 Corporate aftershock: the public policy lessons from the collapse of Enron and other major corporations, ed. C. Culp, W. A. Niskanen, New Jersey 2003, s. 4.

21 S. Shapiro, Agency theory, dz. cyt., s 279.

22 Wall Street and the financial crisis. Anatomy of a financial collapse, Permanent Subcommittee on Investigations - US Senate, New York 2011, s. 48. 


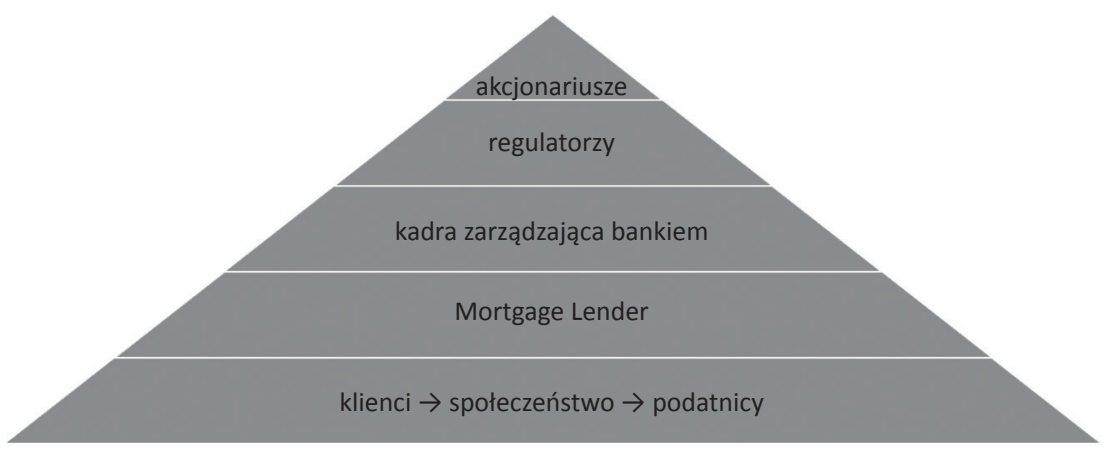

Schemat 1. Pryncypałowie i agenci - przypadek Washington Mutual Bank.

Źródło: opracowanie własne

Podstawowym pryncypałem są w przypadku WaMu akcjonariusze - to oni są właścicielami banku, to oni ponoszą ostatecznie konsekwencje (nie)odpowiedniego zarządzania nim. Agentem akcjonariuszy jest kadra zarządzająca bankiem. Jednak pośrednikiem między rozproszonymi akcjonariuszami - oraz ich kolejnym agentem - są instytucje nadzorujące sektor finansowy - mają one działać w interesie akcjonariuszy poprzez kontrolę banku. Agentem kadry zarządzającej jest Mortgage Lender - firma, której bank jest właścicielem, a która udziela klientom kredytów hipotecznych. Jest to instytucja, która może działać w sytuacji podwójnej lojalności - powinna reprezentować interesy zarówno klientów, jak i swojego właściciela - banku. Gdy interesy tych dwóch podmiotów zaczynają się rozmijać, pojawia się konflikt interesów. W niniejszej analizie ograniczymy się do omówienia trzech głównych obszarów, w których w przypadku WaMu wystąpiły problemy agencji - działań kierownictwa banku, regulatora oraz Mortgage Lender - firmy udzielającej pożyczek.

\section{Kadra zarządzająca WaMu}

Bank Washington Mutual, który działał w sektorze finansowym od końca XIX wieku, historycznie swoją strategię biznesową oparł na udzielaniu kredytów klientom o niskim prawdopodobieństwie niewypłacalności. Jednak w 2003 roku prezes zarządu (CEO) WaMu Kerry Killinger ogłosił, że bank zamierza w znacznie większym stopniu niż do tej pory zaangażować się na rynku ryzykownych kre- 
dytów hipotecznych, udzielanych osobom o niskiej zdolności kredytowej (ang. subprime). Od tego czasu bank zwiększa udział ryzykownych kredytów z 2 proc. w 2003 roku do 54 proc. w 2007 roku²3. W tym samym czasie zwiększa się również o ponad 25 proc. wartość akcji WaMu, a Kerry Killinger zwiększa swoje roczne zarobki z 12 milionów dolarów w 2003 roku ${ }^{24}$ do 21 milionów dolarów cztery lata później ${ }^{25}$. W perspektywie krótkoterminowej udaje się zatem pogodzić interesy pryncypałów - akcjonariuszy - i agentów - managerów. Jednak już od połowy 2007 roku widać pierwsze efekty strategii opartej na ryzykownych kredytach - kurs akcji zaczyna systematycznie spadać. Ponad rok później, 25 września 2008 roku, Washington Mutual Bank ogłasza bankructwo. Na dziesięć dni przez tym wydarzeniem z funkcji prezesa zarządu rezygnuje Killinger i otrzymuje 15 milionów dolarów odprawy. Przykład ten pokazuje, że w długiej perspektywie problemy agencji nie zostały uregulowane w sposób wystarczający. Z perspektywy relacji pryncypałów-akcjonariuszy i agentów-managerów wyłaniają się dwa podstawowe obszary problemowe:

1. Nieuregulowanie problemu asymetrii informacji. Odejście Kerry'ego Killingera tuż przed upadkiem banku, co umożliwiło mu uzyskanie dodatkowych korzyści finansowych pokazuje, jak istotnym, dotychczas nieuregulowanym problemem agencji w sektorze finansowym jest problem asymetrii informacji. Jednym $z$ aksjomatów teorii agencji jest przewaga informacyjna agenta nad pryncypałem. Historia ostatnich dni WaMu empirycznie potwierdza hipotezy, jakie można wyprowadzić z teorii. Możemy domniemywać, że bez stworzenia efektywnego systemu monitorowania agentów podobne sytuacje będą powtarzały się w przyszłości.

2. Nieefektywność kontraktów zorientowanych na wynik. Spektakularny sukces rynkowy WaMu po wprowadzeniu strategii opartej na udzielaniu ryzykownych kredytów, jak i jego równie spektakularny upadek rzucają nowe światło na zasadność powszechnego stosowania kontraktów zorientowanych na wynik. W założeniu jest to podstawowe narzędzie mające na celu utożsamienie interesów pryncypała i agenta. Jednak fakt, iż to właśnie pryncypał ponosi ostateczne konsekwencje za działania agenta (w postaci

23 Wall Street and the financial crisis, dz. cyt., s. 69.

24 K. Grind, The lost bank: the story of Washington Mutual - the biggest bank failure in American history, New York 2012, s. 94.

25 Tamże, s. 174. 
wartości akcji), podczas gdy agent może w każdej chwili odejść, zatrzymując wypracowane wynagrodzenie, w sektorze finansowym może być silnym bodźcem do podejmowania działań ryzykownych. W tym kontekście możemy stwierdzić, że wynagradzanie managerów za pomocą kontraktów zorientowanych na wynik może przyczynić się do zintensyfikowania problemu pokusy nadużycia.

\section{Regulator - Office of Thrift Supervision (OTS)}

Zadaniem regulatora w sektorze finansowym jest $z$ jednej strony dopilnowanie przestrzegania obowiązującego prawa, $z$ drugiej dostarczenie informacji akcjonariuszom o rzeczywistej kondycji instytucji, w którą zainwestowali swoje pieniądze. Niestety Office of Thrift Supervision - główny regulator WaMu - nie wywiązał się z tego zadania. OTS wiedział o ryzyku związanym z udzielanymi przez bank kredytami, lecz nie nakazał zmiany strategii biznesowej ${ }^{26}$. Co więcej, te same naruszenia zasad udzielania kredytów były w WaMu identyfikowane przez wiele lat z rzędu, mimo to nie podjęto żadnych działań, które umożliwiłyby ograniczenie ryzyka. OTS utrzymywał wysoki rating banku, wskazując na jego silną pozycję, aż do marca 2008, a średni aż do miesiąca upadku WaMu - września tego roku - mimo iż inna instytucja regulująca działalność banków - Federal Deposit Insurance Corporation (FDIC) - sugerowała jego obniżenie ${ }^{27}$. Dodatkowo ujawniona korespondencja mailowa między regulatorami i zarządem banku wskazuje na dość duży stopień zażyłości między nimi, który stawia pod znakiem zapytania profesjonalny charakter tej relacji28. W jaki sposób problemy agencji mogły przyczynić się do pojawienia i trwania wymienionych wyżej problemów?

1. Kontrakty zorientowane na zachowanie. Przykład OTS wskazuje na długoterminową nieefektywność tego typu kontraktów w przypadku regulatorów. Instytucja państwowa nie dysponuje odpowiednimi narzędziami nagradzania pracowników działających efektywnie - identyfikujących zagrożenia i działających na rzecz zmiany niedozwolonych praktyk. Brak bodź-

26 Tamże, s. 223.

27 Tamże, s. 274.

28 Wall Street and the financial crisis, dz. cyt., s 213. 
ców skłaniających do efektywności może być jedną z głównych przyczyn nieprawidłowości w instytucjach kontrolnych w ogóle.

2. Kontrola działań oportunistycznych. Znane są przypadki zatrudniania przez WaMu byłych pracowników OTS ${ }^{29}$. Nieuregulowanie problemu tzw. "drzwi obrotowych" w sektorze finansowym może prowadzić do wzmacniania działań oportunistycznych pracowników instytucji regulacyjnych. Perspektywa lukratywnego kontraktu w sektorze prywatnym po zakończeniu pracy jako regulator może w istotnym stopniu wpływać na podejmowanie działań niezgodnych z formalną misją instytucji państwowej.

\section{Long Beach Mortgage Company (LBMC)}

LBMC była firmą specjalizującą się w udzielaniu kredytów hipotecznych (ang. mortgage lender), należącą do WaMu. Również w tym przypadku kadra kierownicza wynagradzana była na zasadzie kontraktów zorientowanych na wynik. Przyjętym wskaźnikiem osiągniętego wyniku była liczba udzielanych kredytów hipotecznych. W połączeniu z nieefektywnymi instytucjami regulacyjnymi doprowadziło to do obniżenia standardów udzielanych pożyczek ${ }^{30}$. Ujawniona dokumentacja LBMC potwierdza, że kierownictwo wiedziało o ryzyku związanym z udzielanymi kredytami, ale nie podjęło się zmiany niekorzystnych praktyk $^{31}$, najprawdopodobniej nie chcąc rezygnować z rocznych bonusów uzależnionych od liczby udzielonych kredytów. Dodatkowo wewnętrzna kontrola przeprowadzona przez WaMu wskazywała, że około 35 proc. dokumentacji umów kredytowych nosi ślady oszustwa. W 14 proc. przypadków zaobserwować można było różnice w podpisach kredytobiorców ${ }^{32}$. Dostępne dane pozwalają stwierdzić, że problem ten ma charakter systemowy - jest niezależny od indywidualnych kompetencji konkretnych managerów. Po stwierdzeniu wymienionych wyżej problemów WaMu zdecydowało się zwolnić dotychczasową kadrę kierowniczą LBMC i powołać doświadczonego managera - Davida Schneidera - jednak mimo tego zabiegu nie udało się rozwiązać zdiagnozowanych pro-

\footnotetext{
29 Tamże, s. 223.

30 Tamże, s. 75

31 Tamże.

32 Tamże, s. 78.
} 
blemów ${ }^{33}$. Możemy postawić hipotezę, że kontrakty zorientowane na wynik stanowią wyjątkowo silny bodziec skłaniający bardziej do realizacji wyznaczonych wskaźników niż postępowania zgodnie z misją instytucji. Przypadek Long Beach Mortgage Company jest egzemplifikacją tego, jak trwałe i nieuregulowane są dwa kolejne problemy agencji:

1. Negatywna selekcja. Jest istotnym elementem, który umożliwia odpowiedzenie na pytanie o to, skąd bierze się nieefektywność kontraktów zorientowanych na wynik. W sytuacji, w której wynik jest określany przez jeden lub więcej wskaźników, agenci mogą być bardziej skłonni do realizacji samych wskaźników bez względu na ich długoterminowe konsekwencje i inne istotne elementy nieujęte we wskaźnikach. Skupienie się na realizacji wskaźników zastępuje formalny cel działania instytucji działaniem zorientowanym na osiągnięcie odpowiednio sparametryzowanego celu.

2. Konflikt interesów. W sytuacji, gdy działanie niezgodne z interesem pryncypała przynosi agentowi korzyści, pojawiają się bodźce do zachowania niezgodnego z formalnymi normami. Identyfikacja potencjalnych konfliktów interesów może przyczynić się do efektywniejszego monitorowania działań agentów i zmniejszyć prawdopodobieństwo oportunistycznych działań agentów.

\section{Zakończenie}

Upadek WaMu ujawnia jedną z ukrytych przyczyn kryzysu finansowego, która leży w nieuregulowaniu w ramach współczesnego kapitalizmu istotnych problemów agencji. Dotychczas wydawało się, że kontrakty zorientowane na wynik sprzyjają utożsamieniu interesów pryncypałów i agentów, jednak działania kadry zarządzającej banków - tu WaMu i LBMC - pokazują, że wytwarzają one bodźce wzmacniające ich długoterminową nieefektywność, co przekłada się na generowanie problemów stawiających pod znakiem zapytania bezpieczeństwo ekonomiczne najbardziej nawet rozwiniętych gospodarek.

Jeśli nie możemy polegać na tego typu kontraktach, kontrola musi odbywać się za pomocą zewnętrznych instytucji - regulatorów rynku. Wskazane działania

33 K. Grind, The lost bank..., dz. cyt., s. 137. 
OTS pokazują jednak, że regulatorzy są takimi samymi agentami jak menedżerowie firm i efektywność ich pracy podlega takim samym problemom agencji.

Współczesne bezpieczeństwo ekonomiczne zależeć będzie w istotnym stopniu od praktycznej możliwości regulowania i zarządzania istniejącymi problemami agencji. Część rozwiązań instytucjonalnych powinna być nakierowana na ich rozwiązywanie. Podejmując działania antykryzysowe poprzez odwołanie do narzędzi wyłącznie ekonomicznych (pakiety stymulujące gospodarkę, obniżanie stóp procentowych itp.), lecz pomijając wymiar regulowania działań agentów, rozwiązanie problemów współczesnego kapitalizmu może okazać się o wiele trudniejsze, niż do tej pory sądzono.

\section{Bibliografia}

Barth J. R., The rise and fall of the U.S. Mortgage and credit markets. A comprehensive analysis of the market meltdown, New Jersey 2009.

Corporate aftershock: the public policy lessons from the collapse of Enron and other major corporations, ed. C. Culp, W. A. Niskanen, New Jersey 2003.

Durkheim É., O podziale pracy społecznej, Warszawa 2011.

Eisenhardt K. M., Agency theory: an assessment and review, „Academy of Management Review" 14 (1989), s. 57-74.

Greenberg A. C., Singer M., The rise and fall of bear stearns, New York-London 2010.

Grind K., The lost bank: the story of Washington Mutual - the biggest bank failure in American history, New York 2012.

Kenworthy L., Economic security. Course at sociology and political science, http://www.u.arizona.edu/ /kenwor/indv102economicsecurity.pdf (14.05.2014).

Kiser E., Comparing varieties of agency theory in economics, political science, and sociology: an illustration from state policy implementation, "Sociological Theory" 17 (1999), s. 146-170.

Masera R., Taking the moral hazard out of banking: the next fundamental step in financial reform, „PSL Quarterly Review” vol. 64 (2011) no. 257, s. 105-142.

Mitnick B. M., Fiduciary rationality and public policy: the theory of agency and some consequences, paper presented at the 1973 Annual Meeting of the American Political Science Association, http://ssrn.com/abstract=1020859 (14.05.2014).

Moe T. M., The new economics of organization, „American Journal of Political Science” 28 (1984), s. 739-777. 
Perrow C., Complex organizations: a critical essay, New York 1986.

Rajan R. G., Fault lines: how hidden fractures still threaten the world economy, New Jersey 2010.

Ronis S. R., Preface, [w:] Economic security. Neglected dimension of national security?, ed. S. R. Ronis, Washington 2011.

Ross S., The economic theory of agency: the principal's problem, „American Economic Review" 63 (1973), 134-139.

Shapiro S., Agency theory, „Annual Review of Sociology” 31 (2005), s. 263-284.

Sharma A., Professional as agent: knowledge asymmetry in agency exchange, "The Academy of Management Review" 22 (1997), s. 758-98.

Wall Street and the financial crisis. Anatomy of a financial collapse, Permanent Subcommittee on Investigations - US Senate, New York 2011.

Waterman R., Meier K., Principal-agent models: an expansion?, „Journal of Public Administration Research and Theory" 8 (1998), s. 173-202. 